\title{
Room Safety System Using Face Recognition Using Telegram and Raspberry Pi Based Histogram of Oriented Method
}

\author{
Azwardi $^{1, *}$ Yulian Mirza ${ }^{1}$ Alan Novi Tompunu ${ }^{1}$ Ariansyah Saputra ${ }^{1}$ \\ ${ }^{1}$ Computer Engineering, Politeknik Negeri Sriwijaya \\ *Corresponding author.Email: azwardi@polsri.ac.id
}

\begin{abstract}
Face recognition is a biometric technology that has been widely applied in security systems. This technology allows us to identify or verify a person's face through images digitally by matching the face texture. Raspberry PI is a small computer that has been installed complete like a real computer using the ARM SoC (System-ona-chip) packaged and in intergration on PCB it uses SD card for booting and long term storage. Telegram is an encrypted chat application that is known to be very safe and has a telegram bot feature can function as a programmable user. The use of raspberry PI added with our camera can use face recognition technology, while the telegram application will send photos someone who tried to enter the room. The communication used is two-way communication that is, the user can perform commands to take photos, move the camera, open the door, lock the door and check the condition of the door by using the telegram application.
\end{abstract}

Keywords: Face Recognition, Face Detection, OpenCV (Open Computer Vision), Computer Vision, HOG, Telegram, Raspberry PI, room safe

\section{INTRODUCTION}

Many things happen in the present crime such as theft, therefore many people employ professionals, like a security guard to maintain property security owned, but it is assessed less effective due to limited manpower human. Humans cannot monitor for 24 hours, other than that it takes a lot of money to pay them. This time the application of computers has grown rapidly just not able to do basic computing will but can do data processing image (image). We can use technology use to monitor security, with image management technology of scientific disciplines learn about image processing techniques in digital referred to as image processing digital (Digital Image Processing).

One of the technologies of digital imagery widely used for security is face recognition that can recognize someone only by using a computer and a camera. So that can be connected to the system to be created, needed an application that can do communication between users and systems, then the system This is made using telegram messenger application which will connect the owner to the system.
Based on the background that has been presented above, the formulation of the problem faced in system design, namely as the following:

a. How researchers this could utilize face recogntion technology in use to secure the room.

b. Create an application that can used to connect with the system this safeguard.

In this study the problems discussed related to security. Utilization face recognition technology, researchers focus limitation problems for face recognition include as follows:

a. Face recognition algorithm (face recognition) is used, namely, HOG which will run on the raspberry PI.

b. Application used to connect with the system is a telegram messenger application which can be used to monitor the system 


\section{THEORETICAL BASIS}

\subsection{Face Detection}

Face detection is one of the very early stages important before the introduction process is carried out face (Face Recegoniton). Face detection considered a special case of object detection. The object class detection task is find the location and size of all objects in the picture that is the face. Detection algorithm faces by matching someone's image little by little. First, the eye area humans that might be detected with test all valley regions in the image level of gray. Then the genetic algorithm used to generate all regions face which may include eyebrows, irises, holes nose and mouth corners. Every face candidate which may be normalized to reduce lighting effect, which was caused by uneven lighting, shirring effect caused by head movement, value the suitability of each candidate is measured based on projections on the eigen face. After all total literacy of all candidates face with high scores are selected for more verification continue. At this stage facial symmetry is measured to determine the face position.

\subsection{Face Recognition}

Face recognition is one biometric technology that has a lot applied in other security systems eye retina recognition, fingerprint recognition and iris. In its own application facial recognition using a camera to catch someone's face later compared to its previous face has been saved in the database. Face recognition is a technology from a computer that make it possible we to identify or verify faces someone through digital images.

\subsection{Histogram Of Oriented (HOG)}

Histogram of Oriented Gradients (HOG) is a feature extraction technique in processing an image that groups the pixel gradient values according to the directional orientation of each local section from the image. The appearance and shape of local objects can often be characterized quite well by distribution of local intensity gradient or direction edge although the exact position is not known gradient or appropriate edge. This is what be the basic idea of the feature extraction technique proposed by Dalal and Triggs. Distribution the gradient or histogram is what becomes a feature for match matching (similarity matching) (Utaminingrum et al., 2017), so that it can be trained into a machine learning. The HOG process is initiated by calculating the slope value with respect to the $\mathrm{X}$ and $\mathrm{Y}$ axes $(\mathrm{G} x, \mathrm{G} y)$ of the difference image pixel value $(B \mathrm{u})$ at the previous index with the image pixel value in the index afterwards according to each axis like an equation (2) and (3).

$\mathrm{G} x(\mathrm{x}, \mathrm{y})=\mathrm{B} u(\mathrm{x}+1, \mathrm{y})-\mathrm{B} \mathrm{u}(\mathrm{x}-1, \mathrm{y})(2)$
$\mathrm{G} \mathrm{y}(\mathrm{x}, \mathrm{y})=\mathrm{B} \mathrm{u}(\mathrm{x}, \mathrm{y}+1)-\mathrm{B} \mathrm{u}(\mathrm{x}, \mathrm{y}-1)(3)$

Information :

G x, G y: gradient image of $\mathrm{X}$ and $\mathrm{Y}$ axes

$\mathrm{Bu}$ : initial image

The gradient image is converted into magnitude the slope $(\varphi)$ is the Euclidean distance of the positions $X$ and $\mathrm{Y}$, and orientation $(\theta)$ is the inverse tangent of positions $\mathrm{X}$ and $\mathrm{Y}$. This process is identical to converting Cartesian coordinates with values the gradient as position values on the $\mathrm{X}$ axis and $\mathrm{Y}$ being the Polar coordinate like an equation (4) and (5)

$$
\begin{aligned}
& \varphi=\sqrt{G_{x}{ }^{2}+G_{y}{ }^{2}} \\
& \theta=\arctan \left(\frac{G_{y}}{G_{x}}\right)
\end{aligned}
$$

Keterangan :

\section{$\varphi$ : Gradient magnitude \\ $\theta$ : Gradient orientation}

Gradient magnitude grouping accordingly the orientation group is carried out in each the local part of the image or called the cell. One cell consists of the pixels of the size you can determined, and from one cell can also be formed a histogram with the number of bin groups that can be determined. Group formation can done by heeding the direction of degrees or not (signed or unsigned ).

Determination of quantity gradient and orientation is done by method trilinier interpolation to find degrees its membership, which consists of interpolation bilinier with respect to cell and linear interpolation with respect to the histogram bin, thus avoiding the aliasing effect, that is, the gradient value will still match when reconstructed. Normalization was carried out in each group cells called blocks. Normalize each block or the local part of the image is carried out for various levels gradient magnitudes can occur in imagery, that is influenced by variations in lighting and contrast background and foreground. Normalization process in a block can be done in a way like one of equation (4)

$$
\begin{aligned}
& \text { L1-norm : } \boldsymbol{f}=\frac{v}{\left(\|v\|_{1}+\varepsilon\right)} \\
& \text { L1-sqrt : } \boldsymbol{f}=\sqrt{\frac{v}{\|v\|_{1}+\varepsilon}}
\end{aligned}
$$$$
\text { L2-Hys : L2-norm, clip(0, 0.2), renorm }
$$$$
\text { L2-norm : } \boldsymbol{f}=\frac{v}{\sqrt{\|v\|_{2}^{2}+\varepsilon^{2}}}
$$

\footnotetext{
information :

$f \quad$ : the histogram vector has been normalized

$v \quad$ : the histogram vector has not been normalized

$\|v\|_{k} \quad$ : normalization vector, normalization type $k=1$ or $k=2$

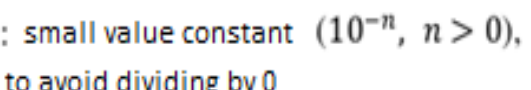




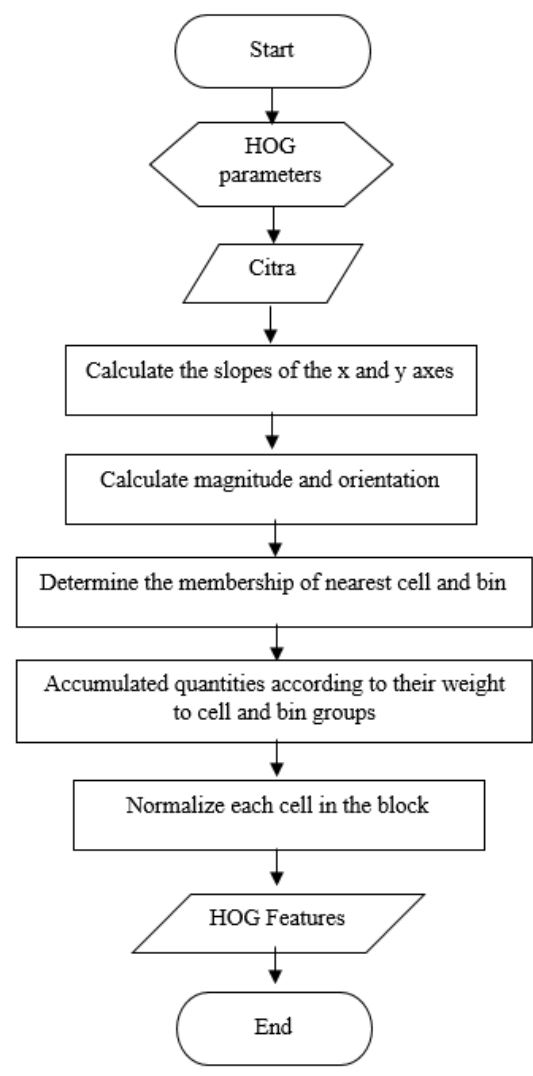

Figure 1: HOG Flow Diagram

By adjusting the distance between parameters stride or overlap, many blocks can have one vector of the cell the same thing, but with different results due to normalization that affected cells on the block. The result of normalization is the end of this method, generate a feature vector which represents the shape of an image. Number of vectors the resulting features can be calculated from the factors number of bins, number of cells produced, and how many many blocks can occur from size selection block and block step. Broadly speaking, grooves Histogram of Oriented Gradients method depicted in Figure 1. To search best face part image HOG parameters as the basis of gender classification, some testing done by changing the function parameters HOG is like cell size, block size, bin number orientation, use of interpolation, block steps normalization, and the type of normalization. Every choice These parameters are used as the basis for build HOG features from all part imagery face. The HOG features are then trained with one kind of method

Table 1 Confusion Matrix Predictions

Actual

\begin{tabular}{|l|l|l|}
\hline & Negatif & Positif \\
\hline Negatif & TN & FP \\
\hline Positif & FN & TP \\
\hline
\end{tabular}

True Positive (TP) : the number of positive class data is classified correctly

False Positive (FP) : number of negative class data is classified incorrectly

True Negative (TN) : the number of negative class data is classified correctly

False Negative (FN) : the number of positive class data is classified incorrectly

Classification with fixed parameters, namely Support Vector Machine (SVM). Linear kernel selection based on the assumption both classes can data separated by a linear function (linear separable). Each model is generated with different HOG parameters then compared to each other so that it can found the best feature HOG parameters with the highest result value.

\section{ANALYSIS PROBLEM AND PROGRAM PLAN}

\subsection{System Work Process}

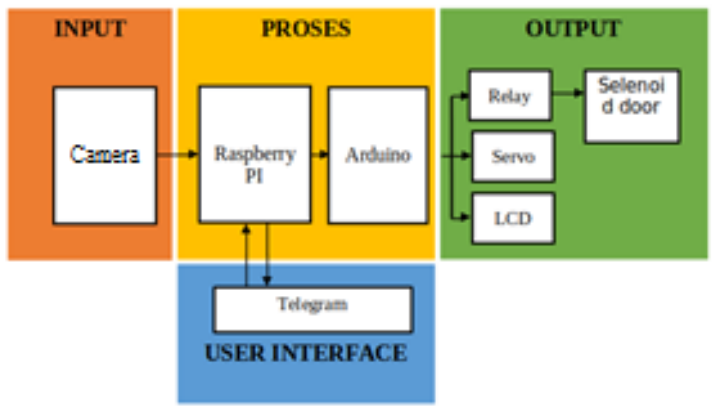

Figure 2: Blok Diagram Kerja Alat

Figure 2 shows where the work process system from the camera input that produces After that, the digital image is processed by Raspberry PI using the HOG algorithm for extracts the feature once it is detected face match if the face is registered on the database then raspberries will send the image results to the telegram and ordered Arduino to open selenoid if not listed then raspberry will send photos of the person and ask permission to open the door through telegram user can grant permission via telegram and also the user can control the direction of the camera using a telegram to be on process by raspberry and spear arduino to move the servo motor, the LCD functions as an indicator of processing results. 


\subsection{Mechanical Planning Plan}

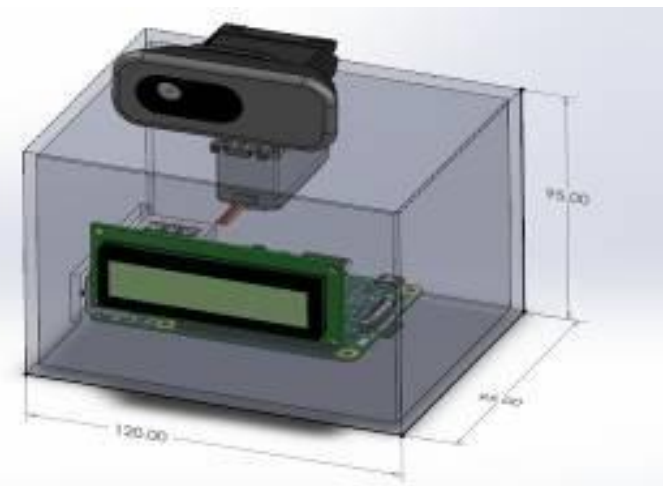

Figure 3: Tool Sketch

Figure 3 describes the design mechanical systems by using multiple acrylic measuring $120 \mathrm{~cm} \mathrm{x} 95 \mathrm{~cm}$ and acrylic measuring $95 \mathrm{~cm} \times 95 \mathrm{~cm}$ to be a house for which component is at the top a hole is made to insert the servo and The webcam is installed above the servo to be able to do tracking on the front made a place for the LCD so that users can see indications are given the LCD in the section side made a hole for the IO port on raspberries and on the back made a hole for the HDMI port and power for raspberry.

\subsection{Electrical Planning Plan}

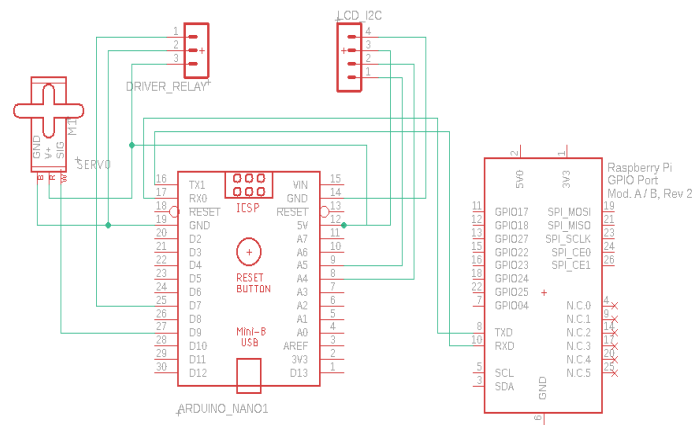

Figure 4: Electrical Equipment

Raspberry PI is connected to a webcam and arduino. Webcam and Arduino connected with Figure 4 describes the schematic connected raspberry PI circuit with a webcam via the USB port to be able receive a digital image, arduino is connected with USB on the PI raspberyy to receive data from raspberry and arduino connected with a servo to control movement the camera is also an LCD which works for provide information to the user in direct and working relay drivers to control selenoids.

\section{RESULTS AND DISCUSSION}

\subsection{Screen Display}

The following is an overview in the application:

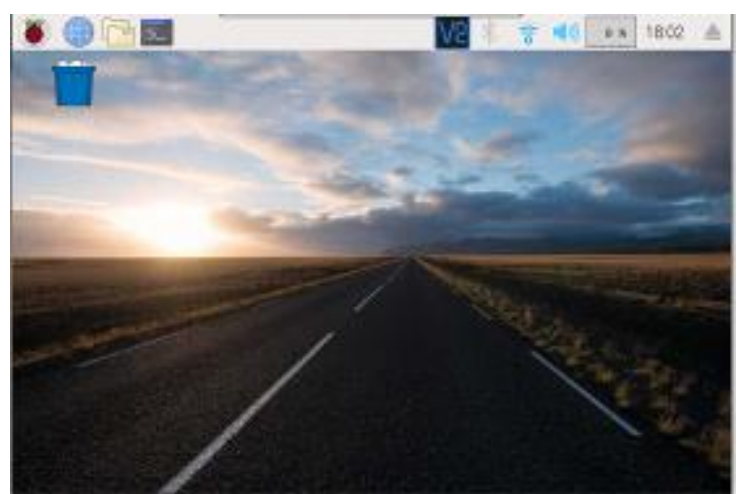

Figure 5: Desktop Screen Display

Figure 5 is the desktop page at raspberry $\mathrm{P} I$ with raspbian OS.

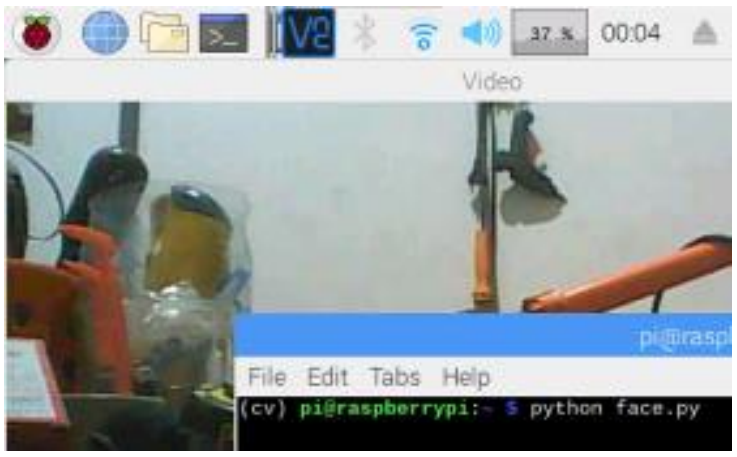

Figure 6: Running Program View

Figure 6 is a face program view running recognition, program do a face search.

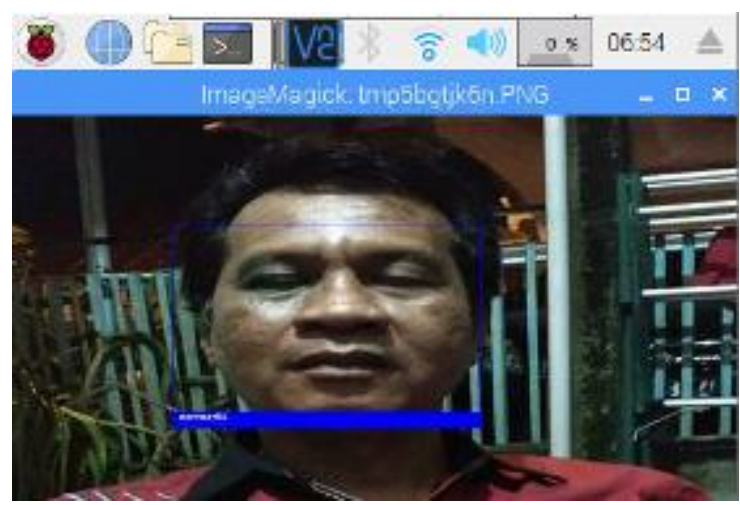

Figure 7: Program Display when Recognized Face

Figure 7 is a display when the program find faces and programs instantly get to know the person by labeling him with the name of the match in the database. 


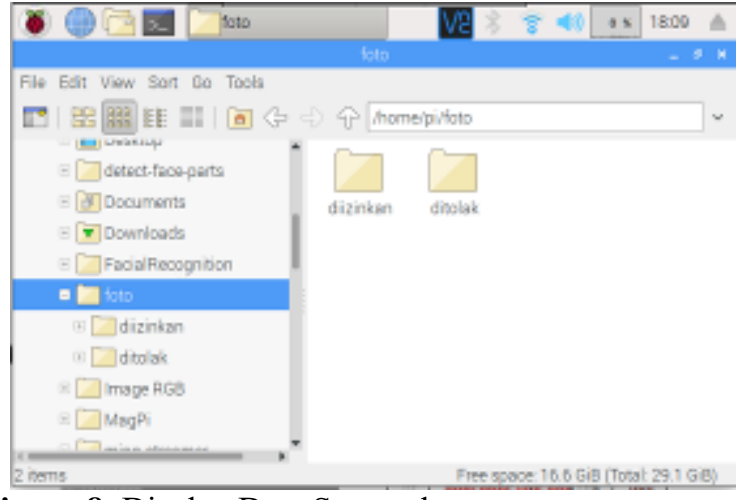

Figure 8: Display Data Screanshoot

Figure 8 shows the storage area photos stored on raspberry memory on The allowed folder is a collection of photos of people known by raspberry while folder rejected is a group of photos that are not known.

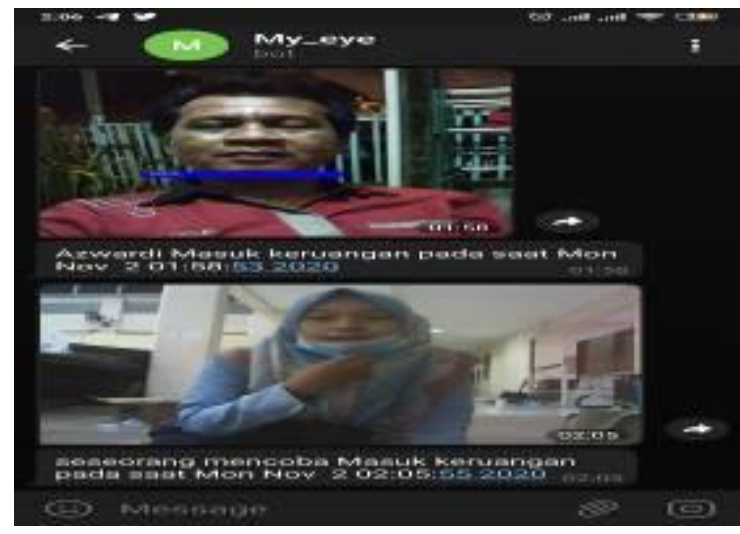

Figure 9: Views on the Telegram Application

Figure 9 shows the appearance of the telegram application when someone tries to enter the room, the system will take a screenshot and will send it to the user's telegram account

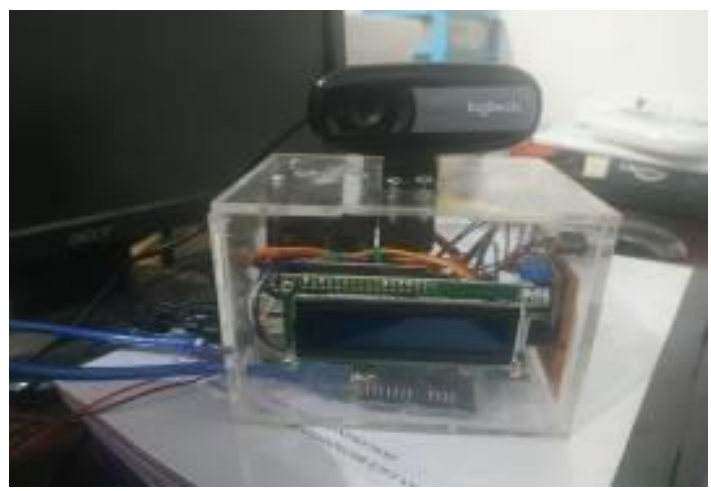

Figure 10: Project View

Figure 10 shows the ready to use hardware.

\subsection{Program Testing}

This tool has a main component in the form of a raspberry pi Arduino camera. The camera will receive data in the form of images that will be processed by the raspberry pi with the HOG method to be able to recognize faces. The face that is recognized and has registered in the system, the raspberry will give a signal to Arduino to unlock the door. The results of the camera reading in the form of a face photo will be sent to the telegram, complete with an explanation in the form of the name, date and time. Meanwhile, faces that have not been registered in the system cannot be recognized, so the door remains closed. The camera reading results in the form of a face photo will be sent to the telegram, accompanied by a description of someone trying to enter without a name, date and time. The working accuracy of this tool will be presented in the table below with ID 1 is registered to the database and the other is not registered:

Table 2. Test Table

\begin{tabular}{l|c|c|c|c|}
\hline No. & Distance & Radiance & ID & $\begin{array}{c}\text { Door } \\
\text { Condition }\end{array}$ \\
\hline 1. & $80 \mathrm{~cm}$ & $64 \mathrm{~lx}$ & 1 & Open \\
\hline 2. & $100 \mathrm{~cm}$ & $641 \mathrm{x}$ & 1 & Open \\
\hline 3. & $120 \mathrm{~cm}$ & $67 \mathrm{~lx}$ & 1 & Open \\
\hline 4. & $100 \mathrm{~cm}$ & $321 \mathrm{x}$ & 1 & Open \\
\hline 5. & $120 \mathrm{~cm}$ & $321 \mathrm{x}$ & 1 & Close \\
\hline 6. & $80 \mathrm{~cm}$ & $31 \mathrm{x}$ & 1 & Open \\
\hline 7. & $100 \mathrm{~cm}$ & $51 \mathrm{x}$ & 1 & Open \\
\hline 8. & $120 \mathrm{~cm}$ & $51 \mathrm{x}$ & 1 & Close \\
\hline 9. & $80 \mathrm{~cm}$ & $64 \mathrm{x}$ & 2 & Close \\
\hline 10. & $100 \mathrm{~cm}$ & $64 \mathrm{x}$ & 2 & Close \\
\hline 11. & $120 \mathrm{~cm}$ & $67 \mathrm{~lx}$ & 2 & Close \\
\hline 12. & $100 \mathrm{~cm}$ & $32 \mathrm{~lx}$ & 2 & Close \\
\hline 13. & $120 \mathrm{~cm}$ & $32 \mathrm{~lx}$ & 2 & Close \\
\hline 14. & $80 \mathrm{~cm}$ & $31 \mathrm{x}$ & 2 & Close \\
\hline 15. & $100 \mathrm{~cm}$ & $51 \mathrm{x}$ & 2 & Close \\
\hline 16. & $80 \mathrm{~cm}$ & $64 \mathrm{~lx}$ & 3 & Close \\
\hline 17. & $100 \mathrm{~cm}$ & $64 \mathrm{~lx}$ & 3 & Close \\
\hline 18. & $120 \mathrm{~cm}$ & $67 \mathrm{~lx}$ & 3 & Close \\
\hline 19 & $100 \mathrm{~cm}$ & $321 \mathrm{x}$ & 3 & Close \\
\hline 20. & $100 \mathrm{~cm}$ & $321 \mathrm{x}$ & 3 & Close \\
\hline & & & & \\
\hline
\end{tabular}

\section{CONCLUSION}

The advantages and disadvantages of applications developed are as following:

a. Program advantages:

1. This tool is easy to operate only by relating it to adapter then the program will run automatic

2. There is a User interface in the form of an LCD $16 \times 2$ which will display the message from raspberry PI.

3. The detection accuracy is quite high.

4. Have a BOT that can do communication between user and device. 


\section{b. Program Cons:}

1.Use of raspberries with memory and low GPU resulted lag in the program.

2.Tool can only recognize faces but can't tell which face comes from a photo or someone's face in real.

\section{REFERENCES}

[1] Devito, D., Wihandika, R. C., \& Widodo, A. W. (2019). Ekstraksi ciri untuk klasifikasi gender berbasis citra wajah menggunakan metode histogram of orieted gradients. Jurnal Pengembangan Teknologi Informasi dan Ilmu Komputer, 3 (8), 8002-8011.

[2] Herlambang, M., \& Dicki. (2016). Rancang bangun keamanan loker dengan autentifikasi wajah dan password berbasis raspberry pi menggunakan notifikasi keamanan via android. Jurusan Teknik Komputer. Politeknik Negeri Sriwijaya.

[3] Lianti, A. (2016). Rancang bangun sistem saklar universal berbasis raspberry pi dengan teknologi websocket. Jurusan Teknik Komputer. Politeknik Negeri Sriwijaya.

[4] Mulyasari, N .L. M. A., Sucianti, N., \& Wijaya,A. Y. (2017). Implementasi deteksi copy-move forgery pada citra menggunakan metode histogram of orieted gradients (hog). Jurnal Teknik ITS, 6 (2), 2337-3520.
[5] Nicco. (2015). Rancang bangun sistem biometrik pengenalan wajah menggunakan principal component analysis. Jurusan Teknik Elektro. Politeknik Negeri Batam.

[6] Prasetyo, H., Muharom, L. A., \& Oktavianto, H. (2016). Penerapan algoritma viola jones pada deteksi wajah. Jurusan Teknik Informatika. Universitas Muhammadiyah Jember.

[7] Rianti, M. (2017). Rancang bangun alat ukur intensitas cahaya dengan menggunakan sensor bh-1750 berbasis arduino. Departemen Fisika. Fakultas Matematika Dan Ilmu Pengetahuan Alam. Universitas Sumatera Utara.

[8] Suryadi, K., \& Sukumbang, S. (2015). Human detection menggunakan metode histogram of orieted gradients (hog) berbasis open_cv. Jurnal Pendidikan Teknik Elektro, 2 (2), 639 645.

[9] Ummah, T. (2017). Deteksi kendaraan menggunakan histogram of orieted gradients dan real adaboost. Skripsi. Institut Teknologi Sepuluh Nopember.

[10] Wijaya, I. D., Nurhasan, U., \& Barata, M. A. (2017). Implementasi raspberry pi untuk rancang bangun sistem keamanan pintu ruang server dengan pengenalan wajah menggunakan metode triangle face. Jurusan Teknologi Informasi. Politeknik Negeri Malang. 